\title{
The Times and Artistry of Segun Adeku: A Neo-Traditional African Artist
}

\author{
Olufemi Joseph Olaleye-Otunla ${ }^{1} \quad$ Eyitayo Tolulope Ijisakin $^{2 *} \quad$ Feyisara Sunday Omolola $^{3}$ \\ 1.Natural History Museum, Obafemi Awolowo University, Ile-Ife, Nigeria \\ 2.Department of Fine and Applied Arts, Obafemi Awolowo University, Ile-Ife, Nigeria \\ 3.Department of Fine and Applied Arts, Olabisi Onabanjo University, Ago-Iwoye, Nigeria
}

\begin{abstract}
This study focuses on the life and artistry of Segun Adeku, a neo-traditional African artist. The study brings to limelight the artist's creative background, ideologies and views about the society, as well as the styles and techniques that have shaped Adeku's artistry over time. This study was conducted through participant observation method, personal contacts and informal oral interviews with the artist. Other information was sourced through exhibition catalogues of the artist's works. The study examines artistic development of Segun Adeku, his sources of inspiration, and critically appraises his works of art. The findings of the study reveal that Adeku is a dexterous neo-traditional African artist who has been preoccupied with forms that are heavily ornamented, using repeated hues and lines to express Yoruba folklores and indigenous stories that preach love and harmony in the society. The study concluded that with Adeku, the theory of the universality of experience holds, whether trained or untrained artists, the difference is only in their sociological make-up. However, this study is neither definitive nor exhaustive in its approach; rather, it serves as an insight into documentation of African artistry so as to avoid going into the oblivion.
\end{abstract}

Keywords: African art, art workshop, neo-traditional artist, Segun Adeku

DOI: $10.7176 / \mathrm{ADS} / 75-03$

Publication date: August $31^{\text {st }} 2019$

\section{Introduction}

Many neo-traditional artists have emerged from the series of occasional art workshops across the continent of Africa. In Nigeria, such workshops include the Society of African Missions (SMA) organized workshop in OyeEkiti (1947-1954) under the directorship of Father Kelvin Caroll (1920-1993); the Mbari Writers' and Artists' Club, Ibadan (1961); the Mbari Mbayo in Osogbo (1962-1964); the Ori Olokun art workshop in Ile-Ife (19681972); as well as the Harmattan Workshop established in (1998) by Bruce Onobrakpeya (b.1932) in Agbarhaotor. A sizable number of the artists from these workshops have resorted to indigenous motifs, myths, and the philosophy of traditional African art using modern techniques and materials. Many of these neo-traditional artists have now trained and influenced newer generations of artists, thus keeping the spirit of neo-traditionalism alive in African art.

Art has been a principal tool for an individual or a group of people in the society to have a grasp and deeper understanding of the physical, spiritual, esoteric, socio-cultural and intrinsic characteristics of their world. It is an effective tool of communication which reflects the historical, social, economic and political conditions of a people which enables viewers to share real understanding and deep sympathy for the artist's felt experiences both the physical and psychic (Okeke, 2006). Klemm (2016) has also argued that many contemporary African artists are influenced by indigenous concepts, and that their art are used to communicate in diverse ways.

Art is considered as one of the greatest form of culture due to the quality of pure expression it offers. Perceiving the artist as a social analyst, Utomi (2011) argues that the visual artist seeks through technical proficiency and skillful manipulation of materials to evaluate, interpret, and affect the course of events in the society. However, due to contacts with other parts of the globe which has led to acculturation, the great variety of artistic expressions witnessed in Africa have also changed, such that artists now look outside their indigenous abode for audience (Olaleye, 2001). Acculturation and its associated consequences, as well as the lingering impacts of colonialism, has also brought both perils and privileges to the cultural landscape in Nigeria such that preferred choices for imported materials seem to be eroding indigenous cultural values (Ijisakin, 2017). It is in this vein that Isola (2002) argues that African media practitioners should be guided by the cultural interests of Africa in their creative endeavours.

Despite the rich artistic and varied cultural heritage of Africa, the continent has suffered serious setbacks by which many artists that have linked traditions and valuable cultural context have not been adequately documented. This study therefore focuses on the life and artistry of Segun Adeku, a neo-traditional African artist. Participant observation method was used while the artist practiced in his studio; informal oral interviews with the artist were conducted and recorded to preserve extant creative cultural traits of the artist. Other information were sourced through comments by individual and corporate critiques of Adeku's works of art, exhibition brochures and fliers of the artist's works as well as photographic documentation of some of the artist's collections. 


\section{Discussion}

The documentation, studies and criticisms of African arts belong to the recent past. While some European scholars have viewed the arts of Africa as unchanged, conservative and not so innovative, Pemberton III (1987) contends that "to judge a work of art from another culture without taking into account its contents constitutes a rupture of the genetic relationship between form and content". In critiquing African traditional art and the neotraditional artists, Abiodun (1987) argues that "students of African art must seek to know the language of a people, their mode of discursive thought and religious expression, the concept and symbols by which a people organize its experiences: the appraisal and evaluation of African arts must now come from within the culture that produces it". This study considers the arguments of Pemberton and Abiodun to be very apt in evaluating the artistic works of Segun Adeku.

As numerous as the race's groups in Africa are, and so fragmentally distributed linguistically; in a similitude, there are also distributed geniuses and artists across the continent that had produced artistic objects of magico-religious importance, objects of ancestral and memorial representations, objects of pride, prestige and decoration, objects of commerce, domestic uses, and architecture; body and fabric decorations, as well as rock and wall paintings to mention but a few. In African past and present, there abound wood, stone, and ivory carvers, bronze casters, potters, painters, and printmakers among others. To the African artist(s), symbolism is very important as well as form, meaning and content which all together are diverse (Olaleye, 2001). Characteristically, distortion in body proportion is a unique feature in African figural representation where the head is generally exaggerated and considered as the center of the being (Gardner \& Kleiner, 2019). The head in African art is considered to be the seat and source of power and intelligence, and the most sensitive to dangers (Brain, 1980). This probably expresses why Adeku attaches so much importance to the rendering of the head and facial expressions in most of his works. African arts are generally multimedia in approach and multifunctional, the representations also have wide array of textural effect and qualities. A critical examination of Adeku's oeuvres would require deep understanding of the canons of African aesthetics, especially that of the Yoruba. More so that importing epistemological tools to bear on traditional African art forms is a dangerous scholarship (Ibitokun 1993). What is drama to the European man may not be drama to the African, especially when their tastes and worldviews are different.

Why do we not know many indigenous African artists and why have they suffered omission and neglect as against what happened to their Western or European counterparts? Many theories, postulations, and guess-works have been put forward by scholars about African arts and artists. In a view to discourage false theories, postulations, and guesswork, efforts must be made to document African artistry. According to Abiodun (1987), researchers in African arts often neglect indigenous philosophical concepts underlying different works of art, this statement therefore is in accordance with the noticeable aesthetic consciousness displayed in Adeku's works that needs to be documented. Adeku's artistry is a reflection of the artist's contact with people and places, this assertion is clearly buttressed by Rousset (1999) who observed Adeku's artistic personality to be characterized by consistent research and creative experimentation in techniques and development of ideas.

\section{Artistic development of Segun Adeku}

Segun Adeku (Plate 1) was born on January 30, 1949; he hails from Ayetoro, Yewa in Ogun State, Nigeria. He started his elementary education at Baptist Day Primary School in Majapa between 1956 and 1958; he completed his primary education at the District Community Primary School, Oke-Offa, Gbongan between 1960 and 1962 ; between 1963 and 1965 Adeku attended St. Patrick's Modern School for his post-primary school education, he lives and practices as a studio artist in Ile-Ife. 


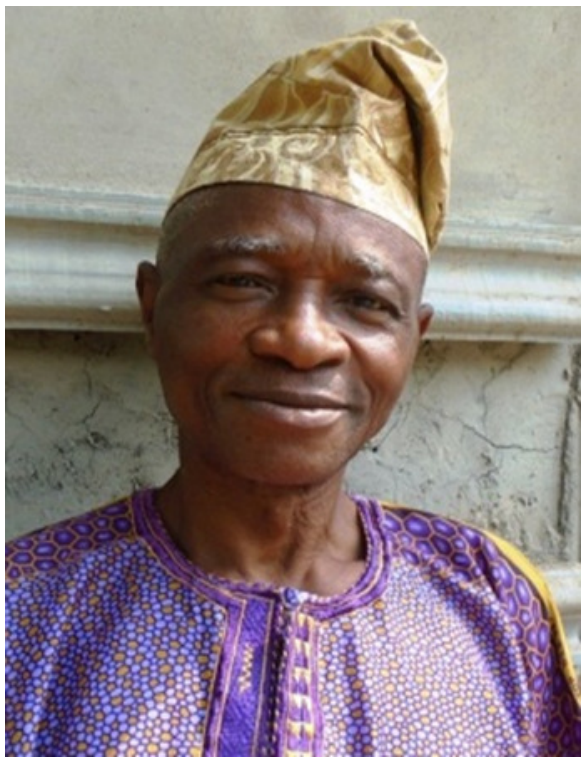

Plate 1: Segun Adeku

Segun Adeku can be grouped with the products of experimental art workshops in southwestern Nigeria. Adeku's interest in art started from childhood, a self-trained artist who never had the opportunity of attending any formal art school, he however derived inspiration from the works of some Ori-Olokun artists like Olayemi Bisiri, Ademola Williams, Tijani Mayakiri and others. Adeku had contacts with some printmakers such as Solomon Irein Wangboje and Bruce Onobrakpeya who have been a source of strong inspiration to him. Segun Adeku claimed to be a disciple of Bruce Onobrakpeya who is a painter, book illustrator, and doyen of printmaking in contemporary Nigerian art; although Adeku did not study under Onobrakpeya directly. Adeku is largely a self-taught printmaking artist whose interest in art received a boost when he strayed into the OriOlokun Art Workshop in Ile-Ife. Adeku was not an official participant at the workshop, he was a freelance observer; however, he benefited immensely from this workshop as he was assisted by Tijani Mayakiri and Ademola Williams.

Adeku operated an art studio known as Olokun Art Gallery, at No 3, Iremo Road, near the King's palace, in Ile-Ife. He recently relocated the studio to his private home, which is off Ilesa Road, Opa in Ile-Ife where he is engaged in various techniques of printmaking such as intaglio-deep etching and relief etching processes. Adeku is an experimental artist who started with wood-cut prints, then lino-prints, painting, calabash carving and a kind of painting on glass which he called 'drawing from the back' - a technique developed by the Dutch artist, Rudolf van Rossem which was not popular until 'Osogbo artists' made it popular. Adeku is a dexterous printmaker who profoundly radiates the use of visual and mythical symbols in unusual ways to communicate his ideas which are primarily focused on his immediate environment. Adeku's works of art evinces his immersion in Yoruba culture; he depicts folklore and everyday subjects with inner joy, contentment, excitement and peace. In the opinion of Falola (2001), Adeku belongs to a small number of highly talented non-university-based artists who are now international figures. Such artists who chose their themes from Yoruba folklore and legends include Jimoh Buraimoh, Nike Okundaye, and Taiwo Olaniyi.

Adeku has been exhibiting his works in Nigeria and outside the shores of the nation since 1970s till date. Adeku exhibited at the Institute of African Studies Museum, Ibadan (2001). He also participated in "Art Within the Community" held at Alliance Francais, Ibadan, February 28 to March 16, 2001; "Echoes, Cities and Artists in Nigeria", Institute of African Studies, University of Ibadan, Ibadan, 2001; at the "Maiden Art Exhibition" of the Society of Nigerian Artists, Osun State Chapter between March 25 to April 8, 2003; and at Ostbevern, Germany, (2007). Adeku also participated in the "Cultural Rebirth" organized by the National Gallery of Art, Osogbo, 2008; as well as in the colloquium "Dialogue between Cultures" organized by the Alliance Francais in celebration of 50 years of cultural relations between Nigeria and France, held in November, 2009 at the National Museum, Lagos. Some of the many prizes and awards won by Adeku include the first prize at the competition organized by the French Governments to commemorate the bicentenary of the French Revolution in 1989, and in the exhibition organized by Alliance Francaise Kano, 1999.

\subsection{Artistic Inspiration of Segun Adeku}

Adeku's inspiration is deeply influenced by his society, he believes that African traditional settings had encouraged and influenced his creativity more than anything else. This is why he would hardly express his 
themes with foreign characters. Adeku prefers to reflect on the Yoruba traditional elements of the past in his works. In his view, the whole world is his abode, he looked at everything as though from a window without bias; according to Adeku "no matter where you go, all over the world, you will always see smiles across faces, and smiles seemed to be harmonious across the globe" hence, the ever smiling figures on his picture planes. The subject matters that have provoked artistic responses of Segun Adeku include peace, unity, tolerance, and sociocultural matters.

\section{Critical Review of Adeku's Art}

A critical look at Adeku's works of art reveals that the main figures are centrally positioned on the picture plane, and there is always a formal balance in the setting of other pictorial elements (see Plates 2 and 3). Large masses are set against other parts of the work, though harmoniously arranged. In Adeku's approach to use of lines, shapes, sizes and colours, there is always heavy contrast between the elements (Plates 4 and 5); the main object at the center of the picture plane is always given dominance over other parts of the work. There is a ubiquitous heavy black outlining of images and figures (Plates 4, 5 and 6) which characterized Adeku's arts, the purpose of which might be a method to give life to the figures from the background. Other adjoining images generally are heavily ornamented with geometric patterns (Plates 6 and 7). Adeku favours the use of zoomorphic figures (Plate 7) to emphasize symbolism of his representations. Thematically, cultural matters, myths, folklore, history, social and political commentaries are Adeku's derivatives. His preoccupation is using forms that are heavily ornamented, repeated with hues and lines to preach harmony (Plate 3), love (Plate 6), as well as kindness and good neighborliness (Plates 8 and 9). Smile costs nothing but achieves a lot. Smile goes a long way in reducing acrimony, anger, bitterness, and hatred in the society; it can also help in maintaining personal health through a mind that is free of bickering and animosity. The smiles as evident in most of the works of Segun Adeku portray him as an unrepentant and ardent advocate of love in the society.

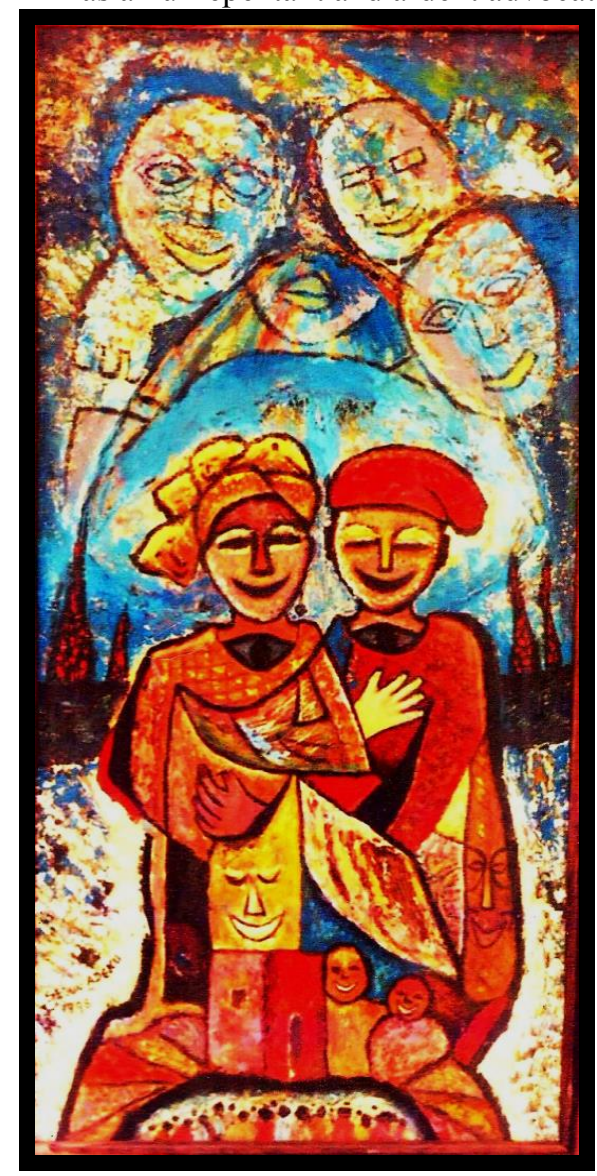

Plate 2: Manageable Few Oil Painting on Board $(90 \times 60 \mathrm{~cm})$ Segun Adeku (1999) Source: Collection of the Artist

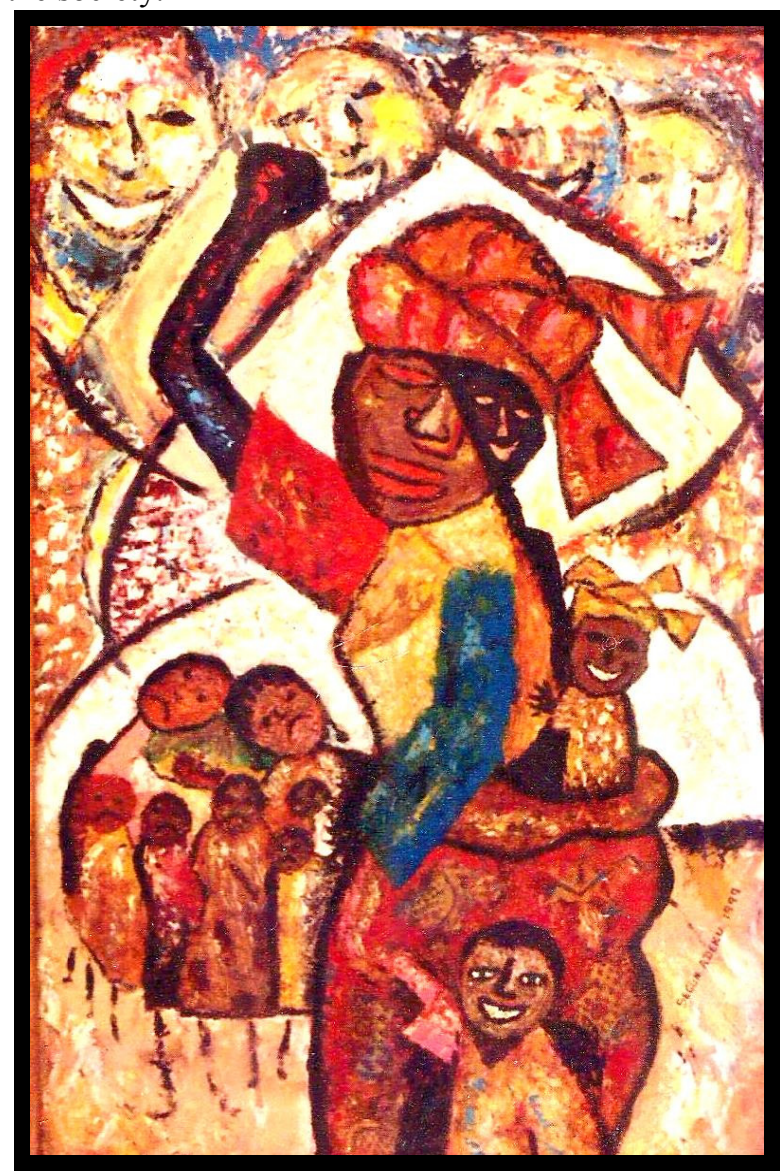

Plate 3: Harmony

Oil Painting on Board (240 x 60cm)

Segun Adeku (1998)

Source: Collection of the Artist 


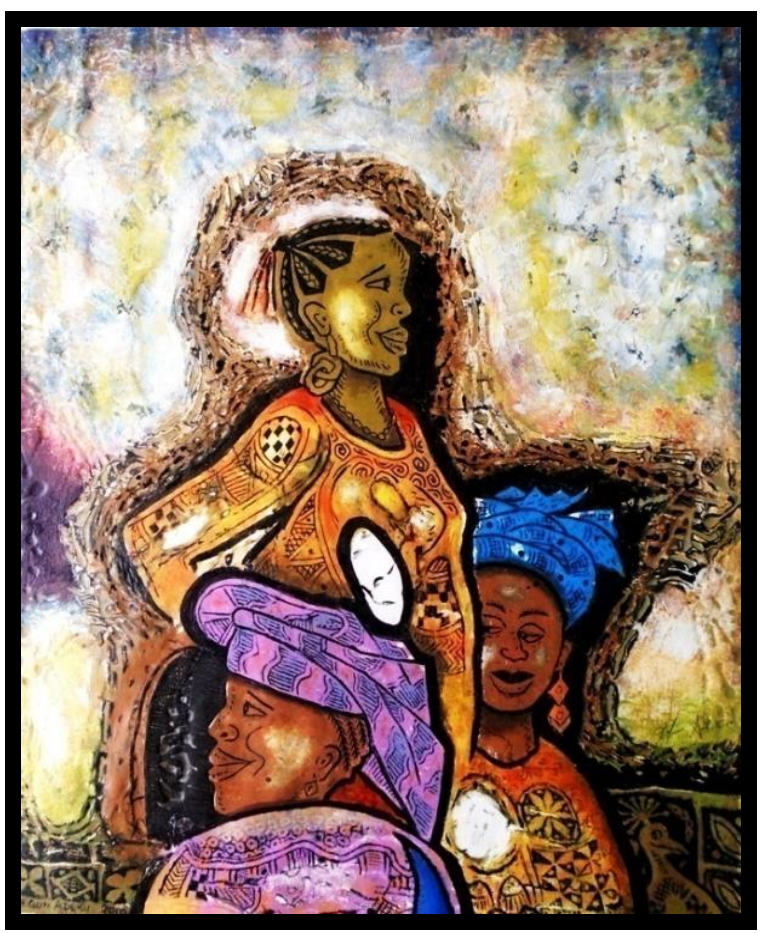

Plate 4: Beautiful Ladies

Deep Etching Print on Paper $(41 \times 51 \mathrm{~cm})$

Segun Adeku (2010)

Source: Collection of the Artist

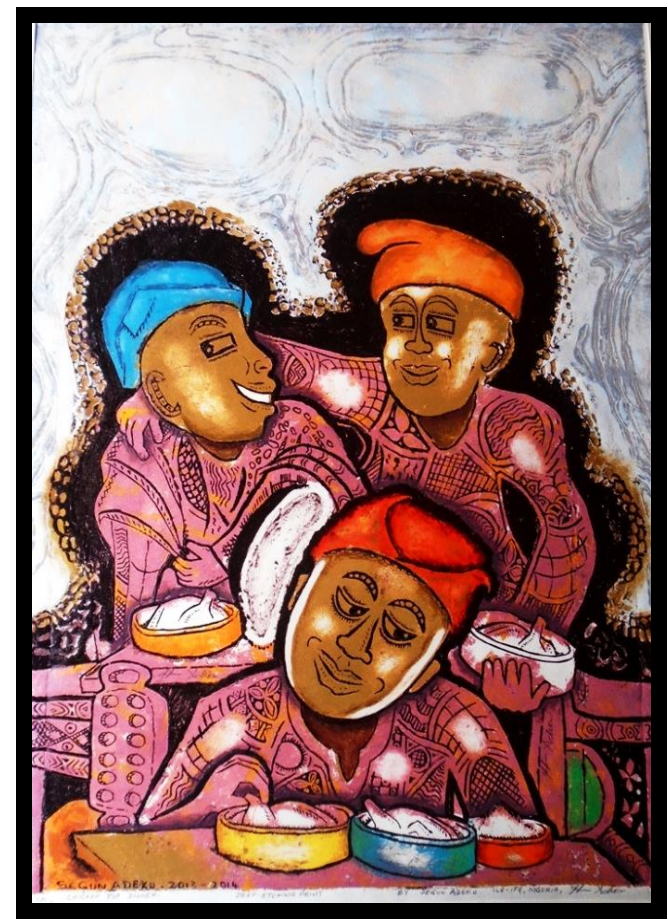

Plate 5: Chicken for Dinner

Deep Etching Print on Paper (46 x 62cm)

Segun Adeku (2014)

Source: Collection of the Artist

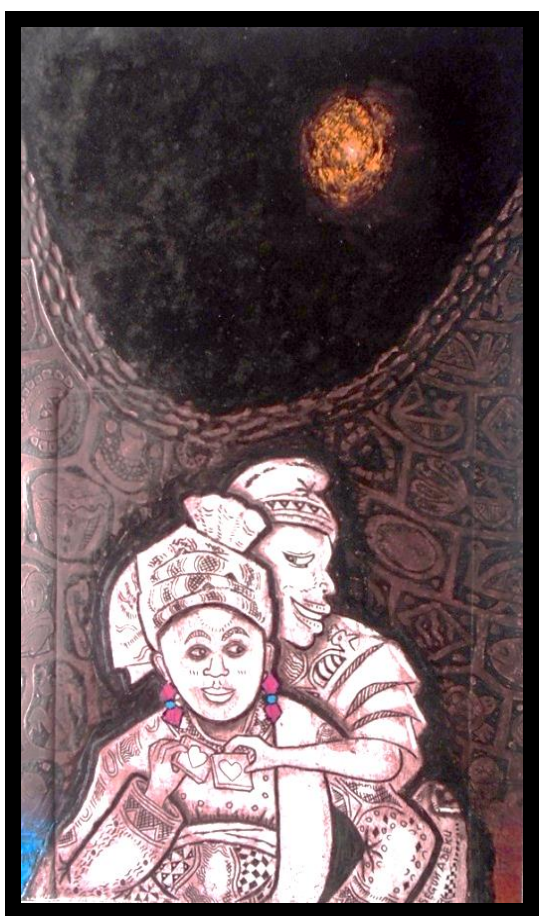

Plate 6: Card of Love

Deep Etching Print on Paper $(31 \times 51 \mathrm{~cm})$

Segun Adeku (2011)

Source: Collection of the Artist

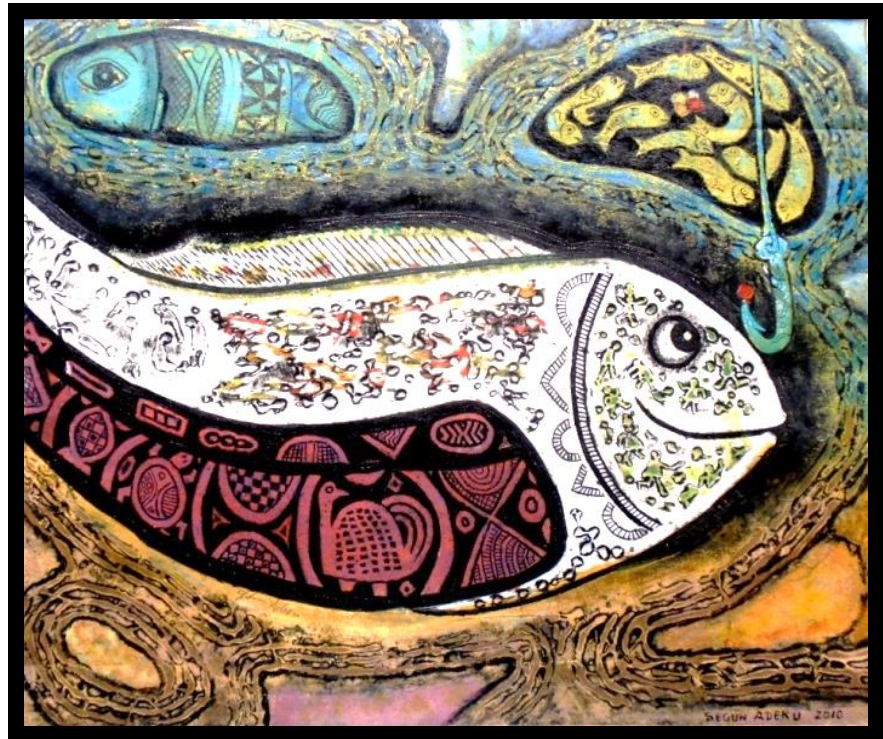

Plate 7: The Lecturer

Deep Etching Print

(41 x $51 \mathrm{~cm})$

Segun Adeku (2010)

Source: Collection of the Artist 


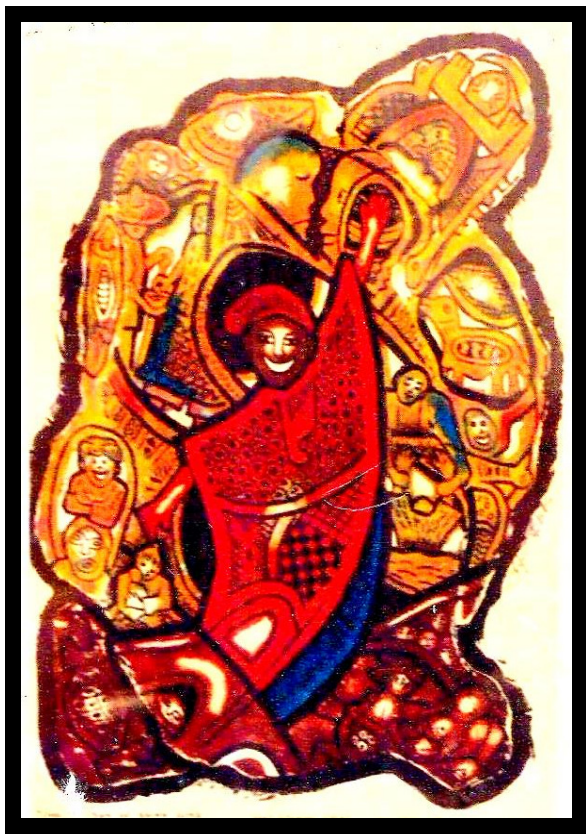

Plate 8: Joy of Doing Good

Etching Print on paper $(42 \times 30 \mathrm{~cm})$

Segun Adeku (1999)

Source: Collection of the Artist

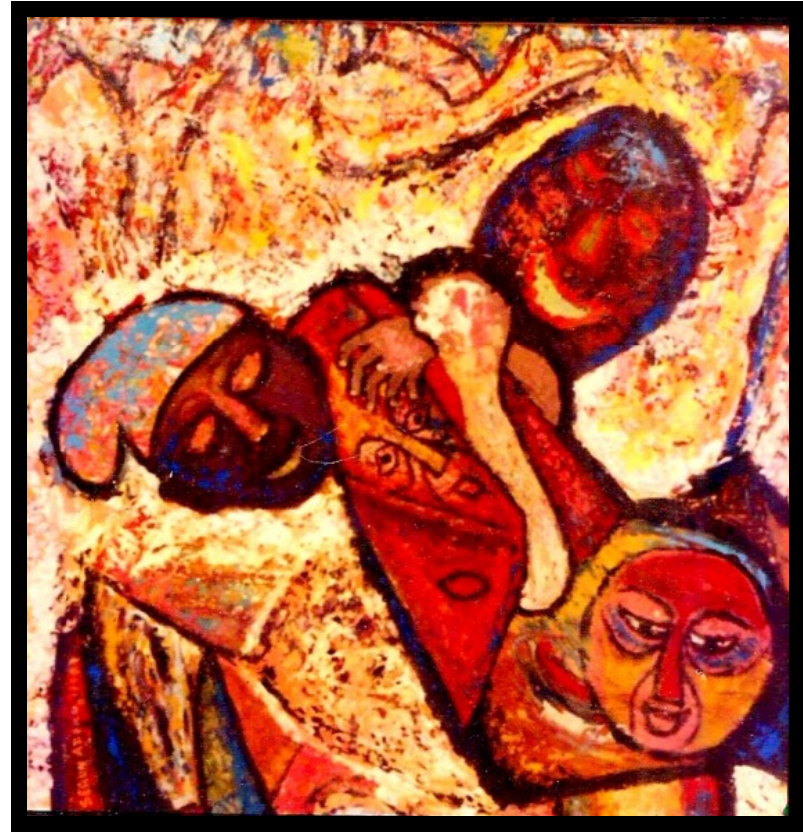

Plate 9: Plane of Feeling

Oil Painting on Board

$(56 \times 61 \mathrm{~cm})$

Segun Adeku (1998)

Source: Collection of the Artist

The spatial analysis of Adeku's picture planes shows that his approach is generally devoid of traces of formal (scholastic) treatment or easel painting traditions such as perspective, foreshortening, organization of the pictorial surface and the use of colour theories and principles. While displaying the character of 21 st century artists, it is difficult to pin him down to a particular art movement: he experiments with his 'loved-medium' deep etching print; he invents new forms and reconstructs reality from his own private experience. Flat surfaces are delicately embellished with decorations, using warm and bright colours.

Adeku partially exhibits the traits of the Fauve artists of late nineteenth and early twentieth centuries that were noted for a more personalized form of expression, varied subject matter and rich surface textures, the use of linear patterns and boldly clashing effects of primary colours with heavy black out-lining (Plates 4, 5, and 7) like the medieval stain-glass. Typically like most traditional and contemporary artists, Adeku puts so many elements together on the pictorial plane regardless of space and other visual attributes just like the works of Yoruba traditional carvers.

\section{Conclusion}

Adeku is an artist who is more than any local craftsman or 'road-side artist'. He displays high technical mastery of his arts with consistency in the use of modern materials like offset printing ink, oil paints, enamels, resin, brushes, pen and ink to enhance the monumentality of his works. Adeku mounts his prints in frames and covers them with glass to prevent ageing and destruction.

As an artist, Adeku specializes in painting, tie-dye, batik, lino and deep etching prints; very conscious of the division of the picture plane into the background, middle ground and foreground. Adeku recognizes the importance and effects of light and shade on pictorial figures; his colour application can be termed one of a 'universal application', though harmoniously placed together; he uses virtually every colour whenever he works. Adeku's design elements are always well-managed with dominance of shapes, lines, colours and form; the contrast between his artistic elements and direction plays a major role in the organization of his picture surface. Adeku's images are very much symbolic and expressionistic, telling stories which can be easily discerned.

To be innovative requires deep creative thinking by "exploring, experimenting, questioning assumptions, using imagination and synthesizing information" (Ijisakin Ademuleya, and Ajiboye 2019). In this, Adeku has been able to intelligently explore indigenous motifs, myths, and the philosophy of traditional African art combining improvisation with modern techniques and materials in creating profound works of art. This discourse about Segun Adeku espouses the theory of the universality of experience, that is, whether trained or untrained artists, their differences being only in their sociological make-up, because all artists recourse back to nature to 
gain experience and knowledge for their practices.

\section{References}

Abiodun, R. (1987). “The Future of African Art Studies: An African Perspective". In African Art Studies: The State of the Discipline. Washington: National Museum of African Art, Smithsonian Institution.

Brain, R. (1980). Art and Society in Africa. London: Longman.

Falola, T. (2001). Culture and Customs of Nigeria. Westport, Connecticut, London: Greenwood Publishing group.

Gardner, H., \& Kleiner, F. S. (2019). Gardner's Art through the ages: A global history. Boston, Mass: Cengage Learning.

Ibitokun, B. M. (1993). Dance as Ritual Drama and Entertainment in the Gelede of the Ketu-Yoruba subgroup in West Africa: A study in traditional African feminism. Ile-Ife: Obafemi Awolowo University Press Ltd.

Ijisakin, E. T. (2016). Interview with Segun Adeku (68) Printmaking artist, Olokun Art Gallery, Ile-Ife, February, $12,2016$.

Ijisakin, E. T. (2017). "Printmaking as a vehicle for navigating the cultural space in contemporary Nigerian art". A paper presented at the PROSPA Publishing Workshop organized by the Arts of Africa and the Global Souths, Rhodes University, South Africa, in conjunction with the Margaret Trowel School of Industrial and Fine Arts, Makerere University, Uganda.

Ijisakin, E. T., Ademuleya B. A., and Ajiboye O. J. (2019): "The making of prints: forms and techniques of printmaking in Nigeria" Arts and Design Studies, a Journal of the International Institute for Science, Technology and Education, New York. https:/iiste.org/Journals/index.php/ADS/article/view/47001 Accessed on July 25, 2019

Isola, Akinwumi (2002): "Cultural Imperatives for African Media Practitioners" in Ife: Journal of the Institute of African Studies, Obafemi Awolowo University, Ile-Ife, 8, 15-26.

Klemm, Peri (2016). "The Reception of African Art in the West," in Smarthistory, https://smarthistory.org/thereception-of-african-art-in-the-west/. Accessed on July 25, 2019

Okeke, C.(2006)."Search for the Theoretical Basis of Contemporary Nigerian Art” In Symposium on Nigerian Art, Lagos: National Gallery of Nigeria.

Olaleye, O. J. (1999). Interview with Segun Adeku at Olokun Art Gallery, Enuwa, Ile-Ife, August, $18,1999$.

Olaleye, O. J. (2001). "Segun Adeku: Profile of a Neo-traditional Artist". Unpublished (M. A.) Dissertation, Department of Fine Arts, Obafemi Awolowo University, Ile-Ife.

Pemberton III, J. (1987). "Response" In African Art Studies: The State of the Discipline Washington: National Museum of African art, Smithsonian Institution, 1987.

Rousset, J. M. (1999). “The Smiling World of Adeku”. Exhibition flier Alliance-Francaise of Kano, 2nd - 9th July, 1999.

Utomi, P. (2011). "Dele Jegede: Between Intellect and Talent” In Peregrinations: A Solo Exhibition of Drawings and Paintings. D. Jegede (ed). Lagos: Nike Art Gallery.

Olufemi Joseph Olaleye-Otunla is a scholar of African Arts; he studied at Obafemi Awolowo University, IleIfe, Nigeria. He is an artist, and a scientific illustrator with bias for African art history, theory and criticism; museum studies and exhibition. He is a member of the Society of Nigerian Artists, and the Nigerian Field Society. He has published his research findings in reputable local and international journals.

Eyitayo Tolulope Ijisakin holds $\mathrm{PhD}$ in African Art Studies from Obafemi Awolowo University, Ile-Ife, Nigeria. He is a Fellow of the American Council of Learned Society in the African Humanities Program (AHP). He was a NRF/SARChI Postdoctoral Research Fellow with the Arts of Africa and the Global Souths, Department of Fine Arts, Rhodes University, South Africa. He is a member of the Advertising Practitioners Council of Nigeria; the Society of Nigerian Artists; and the Nigerian Field Society. He has conducted intensive research on contemporary arts in Nigeria, and has published his research findings in reputable local and international journals.

Feyisara Sunday Omolola holds MFA (2007) in Graphic Design, and currently on MPhil programme in African Art Studies from Obafemi Awolowo University, Ile-Ife, Nigeria. His research interest in African arts has yielded a few publications in journals and conference proceedings. 